\title{
PROLOGUE:
}

\section{No Monument, No Plaque}

Jack Hall didn't care what history thought of him. "I don't want to write history. I just want to make it," he told his lifetime adversary Arthur Rutledge in the days when they were on speaking terms.

Hall was not sentimental. He left no personal papers. He attached no importance to funerals or memorial services, although he himself was capable of delivering a moving eulogy.

His own ashes sat for eighteen days in a cardboard box on the dresser of his half-brother, John Junior Hall, before they were scattered on the waters of the Hilton Hawaiian Village. "You can take my ashes and flush them down the toilet; I wouldn't care," he told his brother.

Hall came to Hawaii in his twenties, a skinny seaman wearing sailor moku (blue denim) pants and a T-shirt. At one time he slept on the floor on spread newspapers or slept down at the docks; sometimes he washed his clothes and took a bath at the same time by plunging into the harbor.

He went from an ordinary seaman to the pinnacle of power. For years he and John A. Burns, the governor, were the two biggest men in the islands, and Hall was the biggest power broker. Politicians from Burns on down approached him openly or by the back door.

Hall loved politics. When he spoke of politics, "his face lighted up." To keep its gains, he said, the union had to play politics. He played it to the hilt. "We simply believe that laboring people should have their say on how our government is run and what laws our legislative bodies enact," he said. He adopted and put into force the old laboring man's battle cry: "Reward your friends and punish your enemies." 


\section{xii Prologue}

"Organized pressure of working people gave Hawaii the best labor and social legislation in the country," said Hall. He kept a hard eye on the politicians who made promises to the union in return for support. He did not threaten or pound the table. He said promises were made to be kept and if they weren't, the ILWU would get its revenge at the polls. He did not like the politically independent, whose behavior he could not predict. He could not tolerate the Tom Gills of politics.

For years Hall and Burns were close allies. Once Burns had scolded him for trying to capture the Democratic Party. "You run the union and I'll run the politics," Burns told him. Hall helped elect Burns governor in 1962 and during Burns' three terms in office the ILWU was his powerful friend-which led to the frequent accusation that Burns was in Hall's pocket.

Their paths did run parallel courses. Their goals often were the same. They had no trouble getting along. "I never had to talk too much to Jack Hall," said Burns. "We'd understand each other.... I never had any pressure placed on me, or anything else. . . . Jack would come to me. 'If you can do this, we'd appreciate it being done.' "'

There was no quid pro quo, said Burns. "After all, the union is realistic. And I imagine they've had to deal. Some of the people I know they've had to deal with that way. On a straight-trade basis. But for me, the hell with it! I'm not interested in that."

Hall was regional director of the ILWU in Hawaii for twentyfive years. He developed into a skilled negotiator, a tough bargainer, a man "with an IBM machine for a brain."

The ILWU in Hawaii gave workers strength they never had before. For the first time labor confronted management on equal terms. Laboring men and women elected their own choices for office. It was a political revolution and Hall led it. The union packed power; it was united. "We have to unite regardless of race, creed or political belief," said Hall.

The man Jack Hall was a mass of contradictions: shyness and arrogance, kindness and malice. Like the five blind men touching the elephant, your opinion of him depended on where you touched him. To many he seemed abrupt and harsh. But to his daughter, Michele (Mikey), "he was a marshmallow." She 


\section{Prologue xiii}

meant that he bled inwardly when he had to do hard things, such as fire an incompetent. That would touch off a drinking spell.

Hall drank. He drank to relieve tension, to escape the endless burdens and problems, or because, as his wife Yoshiko said, he just liked to.

Hall often hurt the people he loved: his wife, his two children, his fellow unionists, his friends. Each man kills the thing he loves, Oscar Wilde said, and Hall did it with arrogance, with unkind words which he seldom apologized for, and with drinking.

His wife, a woman with a core of steel, said: "You know how humiliating it is to have to go look for someone who is drunk. I'd call and I hated to call but I knew he would be sick. He'd heave so much. He'd be really sick, sick, sick. And you can't get angry. So I would just start looking for him."

The search usually began with the old Ala Moana Tropics, the "ILWU Annex," as Robert McElrath, Hall's understudy and replacement as regional director, called it. Hall's great friend was named Jack Daniel and then he made the acquaintance of Jim Beam. "I've seen him drink half a glass of Jack Daniel's [whiskey] straight-before breakfast," said Dr. Willis Butler, Hall's personal physician and confidant.

Butler said Hall was amazingly well disciplined and could stop drinking if Butler ordered him to. "He was not an alcoholic," said Butler. L. Barney McNeil, a reformed alcoholic, watched Hall drinking. "Jack was what people who know drinkers call 'a heavy maintenance man.' He could stop drinking, but he would always start again and in the end it would get him," said McNeil. Once Hall was ordered to limit his drinking to "a little wine." To Hall, said McElrath, "that's two bottles."

Hall was six feet two, and he weighed 218 pounds in his wellfed years. He had a massive chest and shoulders but small feet (size $9 \frac{1}{2}$ ) for so big a man. After one vacation on the mainland, he ballooned to 260 pounds. Illness melted him down in the last years to 160 pounds.

Once when Hall was overweight, Butler told him to limit his food intake to 1300 calories a day. It seemed like a sparse diet, but Hall's sense of humor bubbled. "Not bad," he said. "Four drinks at 300 calories apiece. . . ." 
In the end it all came apart: he had diabetes, prostate trouble, high blood pressure, arteriosclerosis, gout, Parkinson's disease. Yet he refused to feel sorry for himself. He kept struggling to go on working even when he lurched like a paralytic from Parkinson's and could not control his bowels. But if anyone offered an inappropriate word of commiseration, or pity, he cut them down with a withering remark. He was proud, touchy proud, and courageous.

Hall had a "quick, clean mind." He read constantly and absorbed what he read and he kept it on file in his mind. He talked like a lawyer. He wrote like an author. He was a man of extraordinary intelligence.

And yet when Dr. Morton Berk told him in the late 1940s that he was a diabetic, Hall replied: "I like to go home at night and broil a steak for dinner. And I like to have a good shot or two of bourbon before I eat. Diabetes or no diabetes, don't tell me I can't have the drinks because I'm going to anyway."

Hall shot himself daily with insulin. When he went to a Neighbor Island, he carried a thermos of insulin bottles, each equipped with a needle. He learned the technique of shooting himself with insulin by practicing on a grapefruit.

From the time he began reading Communist literature in the 1930s, Hall had a strong left-wing bent and it never wavered. He wrote the following: "Left on trip around the world westward. President Wilson, Dec. 13 [1935]. Arrived S.F. [San Francisco] March 25, 1936. . . . Officially joined the CP [Communist Party] early in 1936, presumably after March 25."

Hall never downgraded the role of the Communist Party in helping build the ILWU. However, he never did state openly that he was ever a member of the Communist Party. People who knew him in the early days in Hawaii said he was a hard-core Communist.

Jack Kimoto, who at one time headed the Communist Party of Hawaii, didn't think much of Hall as a Communist. He said Hall can be regarded as a labor leader, not a Communist Party leader. "I joined the Communist Party to get all the help I could," Hall told his half-brother, John. Hall believed no one 


\section{Prologue xv}

else was effectively helping the working people in Hawaii in those days; only the Communists. And Hall was devoted to the working class. It was his life.

Hall signed the Taft-Hartley Act affidavit every year from 1950 on, which declares that the signer "is not now a member" of the Communist Party. But in his heart Hall never left the Party.

Hall was a name-dropper. He was a gourmet cook. He loved music-from jazz to Beethoven and Mozart. (His wife donated two hundred of his Fats Waller disks and other jazz records to station KQED in San Francisco after he died.) One of his favorite pieces-it would set his feet to tapping and his arms swinging -was "The Gettysburg March," the old New Orleans marching song, with George Lewis on clarinet.

Hall was odd. He could confront management across the bargaining table, but he had trouble changing a light bulb. $\mathrm{He}$ trained himself in accounting, but he couldn't keep a checkbook. And yet he was a mathematical wizard. Hall couldn't drive a car. Ed Berman, in the days when they were friendly, tried to teach him to drive Berman's old Hupmobile, but in vain.

Hall had extremely poor vision. With his glasses off, anything more than four inches from his eyes began to blur. And yet he had remarkable vision; "he could see a very long way down the road," said Tom Hamilton, a former University of Hawaii president. He meant Hall was astute.

Hall was a great poker player. He was a man who hated chitchat. He was intolerant of incompetence, but he was not hard on his help. He had the gambler's instinct. If he had an intuitive feeling about something, he would act on it. He had a mischievous, often casual, attitude about things. "Thirty days in jail never hurt anybody," he used to say. He succeeded so well in Hawaii that by the late 1950s he was "bored, bored, bored," but there was no place to go.

He was not afraid of the employers. The Big Five did not scare him. Yet there he was, a man with a high school education, pitted against the Stanford and Harvard men of Merchant Street.

If you had to use just one word to describe Jack Hall, that 
word would be "pragmatic." He used what he knew would work; he discarded what he knew would not. He looked things over with a cold eye.

Hall loved to deflate the pompous. He loved to tease and even torment the magisterial. He hated affectation. He had a genuineness about him that enabled him to get along with most of the hardhanded men of the ILWU who labored in the fields.

"He didn't talk ... to make you look stupid," said Rick Labez, once his Filipino aide. "The look on his face showed he sympathized with you."

"Hall would work with people, but not be worked by them," said Louis Goldblatt, his friend and mentor. "He took his responsibilities very seriously."

Preparing for a siege at the bargaining table, he often was up until three in the morning, writing in pencil on a yellow legal tablet. Harry Bridges, the ILWU International president who hired Hall (and later regretted it), said Hall was an expert with figures.

No union is just one man or just one leader. If it is to succeed, a union has to be a disciplined army. It was the workers-chiefly Filipinos and Japanese-who made the ILWU strong. They were tough. In fact, they and the coal miners were the most militant union members in the United States.

It was not Hall who did the big organizing of the ILWU in 1944 that suddenly made the union the most powerful force in Hawaii. That credit belongs to Frank Thompson, from Sacramento, and to a host of local people on all the islands. The locals started long before Hall began his life's work.

Hall distrusted doctors, lawyers, intellectuals, and especially professors. He said liberals could be bought or swayed. He preferred a mossback whose stance he could always gauge (or to whom he could dictate) to the liberal who wavered in his allegiance. He had a slogan: "Better an avowed enemy than a double-crossing friend."

Hall was ungainly and unattractive physically, but he did appeal to women. His high cheekbones and wide, straight mouth somehow gave his face a Finnish cast. He couldn't dance or play most sports. He liked to swim and hike. 


\section{Prologue xvii}

Hall was shy about exposing his feelings. He was vulnerable, but few people knew it. He kept most people at arm's length. He felt naked when he marched with thirty-eight others in the first Vietnam War protest demonstration in 1966 in Waikiki.

He could sit for hours enthralled by music. In fact, he could sit for hours wrapped in thought. It was lonely on the heights and he was a lonely man.

They were three remarkable men, Bridges, Goldblatt, and Hall. Though the ILWU was comparatively small, with never more than eighty thousand members in Hawaii and on the mainland, it had these three leaders, all of them radicals. "Enough of them at the top to give the union radical leadership," said Bob Robertson, ILWU International vice-president and director of organization.

For years Hall and Bridges were adversaries, then enemies. Hall and Goldblatt lined up against Bridges and Robertson, but somehow they kept their internal squabbles from being made public. They always presented a united front. It was marvelous acting; they could have contended for an Academy Award. "That's what you had to do," said Bridges. "All things had to be accepted in the interest of presenting a united front. . . ."

Robertson said Hall failed to develop local leadership at the top. "You can't show me one local individual in the islands that he developed into leadership of national prominence," said Robertson. He said Hall was more a political leader than a labor leader. Bridges said Hall took advantage of his political power.

Hall accused Bridges of coming to Hawaii like the conquering hero. "There would be a blare of trumpets and here would arrive Harry on a white horse. . . " Hall claimed that Bridges often "knocked down the ducks"- that is, upset the game plan that Hall might have spent months setting up. Hall complained that no matter how hard he worked Bridges never gave him credit. Bridges laughed at Hall and his frustration.

Hall said Bridges resented the ILWU's achievements in Hawaii; that he was piqued because in Hawaii the ILWU was a bigger force politically than the ILWU on the West Coast.

Bridges called Hall "an ambitious guy-he had some pretty bourgeois ideas. He liked the good life." 


\section{xviii Prologue}

"Jack didn't agree with Harry's attitude toward Hawaii," said Eddie Tangen, a lifetime friend of Hall and no great friend of Bridges:

Jack felt the International was not playing the kind of leadership role in the labor movement it should be playing. . . . It should be doing more, not just sort of administering the day-to-day problems and that sort of thing. That it ought to be out creating again-making the labor movement the vanguard.

Hall made great friends and great enemies. He carried on long-enduring feuds: with Tom Gill and Frank Fasi, the politicians; with Ingram Stainback, the governor; with Rutledge, the labor leader. ("Lou Goldblatt makes the snowballs and Jack Hall throws them," said Rutledge.)

Even within the ILWU Hall irritated people. Some couldn't stand him because he was a haole, a white man from the mainland. Some were jolted by his arrogance and impatience. There was, and still is, racial antagonism among ILWU members, and there always will be: it is a human trait. Some were upset by his drinking.

At one point Hall's relations with Newton Miyagi, the Local 142 secretary-treasurer, were so strained that though their offices were just a few feet across the hall, they didn't speak to each other. "We wrote notes," said Miyagi. "To this day nobody knows. Everyone thought we were the best of friends."

As the years went by and Hall mellowed, some of his best friends turned out to be the people he confronted across the bargaining table. They found him to be a man whose word was good and who had learned their business as well as or better than they themselves. They learned to like him.

Roy Leffingwell, who sat in with employers at sugar negotiations, said: "Hall would say something at three in the morning. Never have I heard anybody question whether Hall would do what he said he'd do. In a labor leader that's an awfully fine quality. He would handle a single plantation with a telephone call. 'Okay, I'll take it.' And he would."

When Hall was convicted in the Smith Act Communistconspiracy trial, the Big Five employers did not exult. They 


\section{Prologue xix}

would rather have dealt with him than with any other labor leader. They trusted him. "From a social outcast he became in the end a statesman," said Bert Kobayashi, associate justice of the State Supreme Court.

He was an uncommon man, Jack Hall, and he helped "turn Hawaii around." He often said he wanted "to be respected, but not to be respectable." He wanted no sweet words of praise, no monument, no plaque. 

Part 1

THE EARLY YEARS

(1915-1940) 
